\title{
Modeling Kinetics of the Water Extraction of Protein from Caragana korshinskii Kom.
}

\author{
Yan-Yan Xie, ${ }^{\text {a,c }}$ Yue-Li Shu, ${ }^{\text {a,c }}$ Dong-Liang Li, ${ }^{\text {a,c }}$ Bo Li,,${ }^{\text {a,c }}$ Zhuo Sun, ${ }^{\text {a }}$ Yang Zou, ${ }^{b}$ \\ Chang-Sheng Qiao, ${ }^{\mathrm{c}}$ Shi-Ru Jia, ${ }^{\mathrm{a}, \mathrm{c}} \mathrm{Zi}-\mathrm{Xuan} \mathrm{Li},{ }^{\mathrm{d}}$ and Cheng Zhong ${ }^{\mathrm{a}, \mathrm{c}, *}$

\begin{abstract}
A two-step extraction method was used to extract proteins from Caragana korshinskii Kom., including a $\mathrm{NaOH}$ solution extraction followed by a water extraction. A power-law model, three-site kinetic extraction model, and second-order model were utilized to investigate the mechanism of the water extraction process and the key factors affecting the protein yield. The experimental data fitted well with the three-site kinetic model, indicating that the water extraction process included washing and faster and slower stages. In addition, the slower stage was the rate-limiting step. For the water extraction process, the protein yield was increased by decreasing the particle size, increasing the $\mathrm{NaOH}$ concentration, or raising the extraction temperature, among which the extraction temperature was the critical factor for controlling the protein yield.
\end{abstract}

Keywords: Modeling kinetics; Water extraction; Protein; Caragana korshinskii Kom.

Contact information: a: State Key Laboratory of Food Nutrition and Safety, Tianjin University of Science \& Technology, Tianjin, 300457, P. R. China; b: Tianjin Jialihe Livestock Group Co., Ltd., Jinwei Road, Beichen District, Tianjin 300402, P. R. China; c: Tianjin Engineering Research Center of Microbial Metabolism and Fermentation Process Control, Tianjin University of Science \& Technology, Tianjin 300457, P. R. China; d: School of Medicine, Tibet University, Lhasa, Tibet 850000, P. R. China;

* Corresponding author: chzhong.tju@gmail.com

\section{INTRODUCTION}

Caragana korshinskii Kom. (C. korshinskii Kom.), a perennial deciduous shrub, is widely planted artificially in northwestern China due to its excellent performance for conserving soil and water, as well as improving soil fertility (Cheng et al. 2013; Li et al. 2014; Yang et al. 2014). This shrub is generally reaped every 3 years to make it flourish, and as a result, vast amounts of biomass is produced. To date, the residues of $C$. korshinskii Kom. are mainly utilized as animal feed or firewood in rural areas. It has been reported that C. korshinskii Kom. contains high contents of cellulose, hemicellulose, lignin, and protein (Zhong et al. 2012). Thus, C. korshinskii Kom. is a good source of protein, which can ensure necessary nutrients and has health benefits for human beings and animals. The protein recovered from the residues of $C$. korshinskii Kom. has rich amino acids including aspartic acid, glutamic acid, praline, and serine, as well as characteristic physico-chemical properties (Zhong et al. 2012, 2014a). Therefore, it can be potentially used in food, animal feed, cosmetics, and pharmaceuticals industries. Valorization of the biomass into valuable products can generate higher economic value and also reduce the environmental impact.

Extraction of plant proteins from raw material is a complicated process due to the complex structure of plant cell walls. Quantity and quality of these plant proteins are strongly associated with the extraction method. Alkaline extraction is one of the most 
common methods. High yield and purity of proteins can be obtained by using this method (El-Adawy et al. 2001; Zhang et al. 2014). However, high $\mathrm{pH}$ conditions could lead to intermolecular cross-linking and rearrangement, thus decreasing protein nutritive value (Hou et al. 2017; Zhang et al. 2018). It is necessary to take some measures to overcome these drawbacks of the alkaline extraction method. Water extraction has also been used to extract protein, with strong advantages of high quality protein (Sivapriya and Leela 2007; Ndlela et al. 2012). Therefore, a two-step extraction procedure, including alkaline and water extraction processes, is applied to maximize the recovery of protein with minimal changes in biological and chemical properties.

The extraction yield of protein from plant-based materials is closely related to the process operational parameters (Lowry et al. 1951; So and MacDonald 1986; Cheung and Wu 2013; Kiew and Mat Don 2013). To optimize the extraction process, it is important to use mathematical models to analyze the kinetics of protein extraction. As reported previously, a two-site kinetic extraction model and a second-order model have been proposed to study the alkaline extraction process of protein from C. korshinskii Kom. The results showed that particle size, alkaline concentration, and extraction temperature all had effects on its kinetics and protein extraction yield, and the particle size was the key factor (Zhong et al. 2014). However, the mechanism of water extraction of protein from $C$. korshinskii Kom. has not been reported. To enhance the protein extraction yield, it is necessary to investigate the kinetics and key influence factors for the water extraction process.

The extraction of protein with water from C. korshinskii Kom. is a case of solidliquid extraction. Many theoretical kinetic models, including power-law model, three-site kinetic model, and second-order model, have been developed for the solid-liquid extraction process in water and other solvents (So and MacDonald 1986; Cheung and Wu 2013; Goula 2013; Kiew and Mat Don 2013). The power-law model is simple and satisfactory to fit experimental data. The water extraction of protein from C. korshinskii Kom. can be considered to have three simultaneous processes: washing, faster diffusion, and slower diffusion (So and MacDonald 1986). In addition, the second-order model has provided adequate explanation for extraction of food and medicinal products in solvents (Rakotondramasy-Rabesiaka et al. 2007; Qu et al. 2010). Therefore, in this study, the protein was extracted from $C$. korshinskii Kom. by a two-step alkaline extraction and water extraction under different conditions. The kinetics of the water extraction process was evaluated using three mass transfer models, namely the power-law model, three-site kinetic extraction model, and second-order model. The effects of particle size, $\mathrm{NaOH}$ concentration, and extraction temperature on the kinetic coefficients in these three models were investigated. In addition, the three models were analyzed to reveal the limiting factors for the water extraction process.

\section{EXPERIMENTAL}

\section{Materials}

Caragana korshinskii Kom. (C. korshinskii Kom) was picked from Liang Cheng county of Inner Mongolia, China. A desktop shredder (DF-15; Qijiawu Scientific Instrument Factory, Huanghua, China) was used to mill the air-dried leaves and the tissues 
of C. korshinskii Kom. The shredder was equipped with two layers of standard sieves (GB6003-88, Huakang Laboratory Instrument Factory, Shangyu, China) to pass the milled materials. The samples were obtained after milling and sieving through sieves of one mass of C. korshinskii Kom. Two sieves with 20-mesh and 40-mesh, 40-mesh and 60-mesh, and 60-mesh and 80-mesh were used to get samples with particle sizes of 20- to 40-mesh, 40to 60-mesh, and 60- to 80-mesh, respectively. The obtained samples with different grain size were stored at $-20^{\circ} \mathrm{C}$. Sodium carbonate, potassium sulfate, copper sulfate, potassium sodium tartrate and acetone were purchased from Tianjin Beifang Tianyi Chemical Reagent Factory (Tianjin, China). Sodium hydroxide was purchased from Tianjin No. 1 Chemical Reagent Factory (Tianjin, China). Folin-Ciocalteu reagent was purchased from Beijing Solarbio Science \& Technology Co. (Beijing, China). Boric acid was purchased from Tianjin Chemical Reagent Wholesale Department (Tianjin, China). Concentrated sulfuric acid was purchased from Tianjin Yuanli Chemical Co., Ltd. (Tianjin, China). Bromocresol green and methyl red were purchased from Shanghai No. 3 Reagent Factory (Shanghai, China).

\section{Methods}

\section{Protein extraction}

The protein was extracted using a two-step extraction method, namely an alkaline extraction followed by a water extraction. The samples were first treated by alkaline solution using an adjusted method from Zhong et al. (2012). In brief, $1 \mathrm{~g}$ of C. korshinskii Kom. was dispersed in $20 \mathrm{~mL}$ of $\mathrm{NaOH}$ solution at a desired concentration, after which it was incubated in a water bath at $293 \mathrm{~K}$ for $30 \mathrm{~min}$. Next, the resulting mixture was filtered, and the solids were collected for the subsequent water extraction of protein. The collected solids were soaked in $20 \mathrm{~mL}$ of deionized water in a water bath at a desired temperature for $5 \mathrm{~h}$. The appropriate amount of the supernatant of the mixture was collected at intervals of $5,15,25,35,60,90,120,180,240$, and $300 \mathrm{~min}$ for the protein determination. When study the effect of particle size, the alkali concentration for the alkaline extraction process was $0.06 \mathrm{M}$, and the extraction temperature for the water extraction process was $293 \mathrm{~K}$. When studying the effect of alkali concentration, the particle size of the samples was 40to 60-mesh, and the extraction temperature for the water extraction process was $293 \mathrm{~K}$. When studying the effect of extraction temperature for the water extraction process, the particle size of samples was 40- to 60-mesh, and the alkali concentration in the alkaline extraction process was $0.06 \mathrm{M}$.

\section{Protein determination}

The protein content in C. korshinskii Kom. determined by the method of Combustion Nitrogen Analysis was $80 \mathrm{mg} \mathrm{g}^{-1}$. The Lowry's Method was used to determine the protein content in the extraction solution (Lowry et al. 1951). Accordingly, the protein measurement was carried out using Folin-Ciocalteu reagent. Bovine serum albumin was used as the standard. The absorbance at $500 \mathrm{~nm}$ was measured on an ultraviolet (UV) mini1240 spectrophotometer (SHIMADZU, Otsu, Japan). The protein extraction yield from $C$. korshinskii Kom. at extraction times of 5, 15, 25, 35, 60, 90, 120, 180, 240, and 300 min under various particle sizes, alkali concentrations and extraction temperatures were presented in the Tables S1, S2 and S3, respectively. 


\section{Kinetic Models for the Water Extraction Process}

Power-law model

The power-law model has been widely applied to describe the solid-liquid extraction process, such as alkaline extraction of protein from freshwater fish (Kiew and Mat 2013) and extraction of water-soluble components from fungus (Cheung and $\mathrm{Wu}$ 2013). It can be expressed by Eq. 1,

$$
C_{\mathrm{t}}=b \times t^{\mathrm{n}}
$$

where $C_{\mathrm{t}}$ is the extracted protein in the water extraction process ( $\mathrm{mg} \mathrm{g}^{-1}$ dry weight) at a given exaction time $t$ ( $\mathrm{min}), b$ refers to the constant correlated with the extraction rate and the power-law exponent, and $n$ is the diffusional exponent $(<1)$.

Transforming Eq. 1 into a logarithmic style, its linearised form can be obtained as Eq. 2:

$$
\ln C_{\mathrm{t}}=n \ln t+\ln b
$$

Three-site kinetic extraction model

According to the study by So and MacDonald (1986), the water extraction of protein from $C$. korshinskii Kom. can be considered to have three simultaneous processes: washing, faster diffusion, and slower diffusion. After the alkaline extraction, there is still a major part of protein extracted by $\mathrm{NaOH}$ solution on the solid surface. At the initial period of the water extraction process this part of protein can be removed quickly by simple washing from the solid surface. In addition, the remaining protein is extracted through two parallel diffusional processes from the interior of the solid. Most of the remaining protein is derived quickly from the broken cells, while the other remaining protein removal from the intact cells requires a much longer time. Therefore, a three-site kinetic model can be used to analyze the water extraction of protein from C. korshinskii Kom. The kinetic equation of this model is showed as follows,

$$
\begin{aligned}
& C_{\mathrm{t}}=C_{0} \times\left(1-\exp \left(-k_{0} \times t\right)+C_{1} \times\left(1-\exp \left(-k_{1} \times t\right)\right)+C_{2} \times\left(1-\exp \left(-k_{2} \times t\right)\right)\right. \\
& C_{\infty}=C_{0}+C_{1}+C_{2} \\
& A=C_{\infty}-C_{0}=C_{1}+C_{2}
\end{aligned}
$$

where $C_{\mathrm{t}}$ is the protein extraction yield ( $\mathrm{mg} \mathrm{g}^{-1}$ dry weight) at a given extraction time $t$ (min), $C_{0}, C_{1}$, and $C_{2}$ are the protein yields after infinite time for the washing process, the faster diffusion process, and the slower diffusion process ( $\mathrm{mg} \mathrm{g}^{-1}$ dry weight), respectively; $C_{\infty}$ represents the protein extraction yield at equilibrium ( $\mathrm{mg} \mathrm{g}^{-1}$ dry weight); $A$ refers to the total protein yield of the water extraction process ( $\mathrm{mg} \mathrm{g}^{-1}$ dry weight); and $k_{0}, k_{1}$, and $k_{2}$ are the extraction rates for the washing process, the faster diffusion process, and the slower diffusion process $\left(\mathrm{min}^{-1}\right)$, respectively.

\section{Second-order model}

The second-order model has also been widely used to simulate the solid-liquid extraction process from plants (Rakotondramasy-Rabesiaka et al. 2007; Qu et al. 2010; Goula 2013). In this work, the protein extraction process is assumed as:

Protein (s) + water (aq) $\longrightarrow$ (soluble protein in the water) (aq) 
The assumptions are made in this model that the operation is only a function of the soluble protein in suspension, and the protein exaction yield at the equilibrium time is considered constant under the same extraction conditions. The equation of the second-order model can be expressed as,

$$
d C_{\mathrm{t}} / d_{\mathrm{t}}=k \times\left(C_{\mathrm{s}}-C_{\mathrm{t}}\right)^{2}
$$

where $C_{\mathrm{t}}$ is the protein yield of the extraction process $\left(\mathrm{mg} \mathrm{g}^{-1}\right.$ dry weight) at a given extraction time $t$ (min), $k$ refers to the second-order extraction rate constant $\left(\mathrm{g} \mathrm{mg}^{-1} \mathrm{~min}^{-1}\right)$, and $C_{\mathrm{s}}$ represents the protein exaction yield at equilibrium ( $\mathrm{mg} \mathrm{g}^{-1}$ dry weight), which is called extraction capacity. equation,

With the boundary conditions $t=0$ and $C_{\mathrm{t}}=C_{0}$, Eq. 7 can be written as a linear

$$
\begin{aligned}
& C_{\mathrm{t}}=C_{\mathrm{s}}-(1 /(k \times t+a)) \\
& a=1 /\left(C_{\mathrm{s}}-C_{0}\right) \\
& C_{0}=C_{\mathrm{s}}-1 / a \\
& A=C_{s}-C_{0}
\end{aligned}
$$

where $C_{0}$ is the initial protein yield of the water extraction process ( $\mathrm{mg} \mathrm{g}^{-1}$ dry weight), which can be supposed as the initial protein concentration in the water, $A$ can be defined as the total protein yield of the water extraction process ( $\mathrm{mg} \mathrm{g}^{-1}$ dry weight), and the parameter $a\left(\mathrm{~g} \mathrm{mg}^{-1}\right)$ is the reciprocal of $A$.

Excluding $C_{\mathrm{t}}$ and $t$, all the other parameters of the three models were obtained by fitting the experimental data to Eqs. 2, 3, and 8 using regression procedures of the software Origin 8.0 (Originlab Corporation, Northampton, MA, USA), respectively.

\section{RESULTS AND DISCUSSION}

\section{Particle Size}

To study the effect of particle size on the water extraction process, the experimental data in Table S1 were fitted into the power-law model. Figure 1a shows the linear fit of the experimental data for water extraction of protein from C. korshinskii Kom. based on Eq. 2. The values of slope and intercept in Fig. 1a are the values of $n$ and $\ln b$, respectively. A summary of the values of the power-law constant $(b)$, diffusional exponent $(n)$, rate constant $(k)$, and coefficient of determination $\left(\mathrm{R}^{2}\right)$ is presented in Table 1 . Thereinto, $k$ refers to the protein extraction rate constant, $k=b \times n$, which is from the derivative of the power-law model Eq. 1:

$$
d C_{t} / d_{t}=k \times t^{\mathrm{n}-1}
$$

As shown in Table 1, a good linear fit of the experimental data of protein extraction was obtained $\left(\mathrm{R}^{2}>0.98\right)$, indicating that the power-law models could be used to describe and predict the water extraction of protein from $C$. korshinskii Kom. The $k$ value increased from 0.2550 to 0.4441 with the decline of particle size from 20- to 40-mesh to 60- to 80mesh. Similar results were also obtained for the ultrasound-assisted extraction of polysaccharide from medicinal fungus by the finding of Cheung and $\mathrm{Wu}(2013)$ that the 
polysaccharide extraction rate constant rose with the decline of sample size.

Table 1. Fitting Parameters in the Power-law Model Under Various Particle Sizes

\begin{tabular}{|c|c|c|c|c|}
\hline Particle & \multicolumn{4}{|c|}{$\ln C_{\mathrm{t}}=n \ln t+\ln b$} \\
\cline { 2 - 5 } Size (Mesh) & $b$ & $n$ & $k=b \times n$ & $\mathrm{R}^{2}$ \\
\hline 20 to 40 & 2.0336 & 0.1254 & 0.2550 & 0.9842 \\
\hline 40 to 60 & 4.0625 & 0.0937 & 0.3805 & 0.9966 \\
\hline 60 to 80 & 5.0591 & 0.0878 & 0.4441 & 0.9957 \\
\hline
\end{tabular}

A three-site kinetic model was also used to study the effect of particle size on the water extraction process. Figure $1 \mathrm{~b}$ shows the extraction kinetic curves. Three characteristic parameters were used to define an extraction curve: protein yield $\left(C_{0}\right)$ for the washing process, protein yield $\left(C_{1}\right)$ for the faster diffusion process, and protein yield $\left(C_{2}\right)$ for the slower diffusion process. Table 2 presents the correlated results. The parameters $C_{0}$, $C_{1}, C_{1}, k_{0}, k_{1}$, and $k_{2}$ as well as $\mathrm{R}^{2}$ were obtained by fitting the experimental data of $C_{\mathrm{t}}$ and $t$ in Table S1 to Eq. 3. According to Eqs. 4 and 5, the values of $C_{\infty}$ and $A$ were obtained. The three-site model fitted the experimental data well for the samples with particle sizes of 40- to 60-mesh and 60- to 80-mesh $\left(\mathrm{R}^{2}>0.99\right)$. The value of $k_{0}$ was much higher than that of $k_{1}$ and $k_{2}$, suggesting that the washing process occurred instantaneously and the diffusion process was the rate-governing step during the water extraction of protein process. Therefore, Eq. 3 can be simplified as,

$$
C_{\mathrm{t}}=C_{0}+C_{1} \times\left(1-\exp \left(-k_{1} \times t\right)\right)+C_{2} \times\left(1-\exp \left(-k_{2} \times t\right)\right)
$$

The value of $k_{1}$ was higher than that of $k_{2}$, but $C_{1}$ was lower than $C_{2}$, suggesting that the protein release was dominated by the slower diffusion process as the mean particle size was between 40- and 80-mesh (Table 2) (Zhong et al. 2014b). This might be due to the fact that most proteins were released quickly from the broken cells, while only a small amount of proteins were released from the intact cells by the preceding alkaline extraction procedure (Wenjuan et al. 2010). In addition, with the decreasing of the particle size from 40- to 60-mesh to 60- to 80-mesh, there were increases of $C_{0}$ from 4.12 to $5.13 \mathrm{mg} \mathrm{g}^{-1}, C_{1}$ from 1.32 to $1.45 \mathrm{mg} \mathrm{g}^{-1}$, and $C_{2}$ from 1.74 to $1.96 \mathrm{mg} \mathrm{g}^{-1}$ (Table 2). A higher total protein yield of the water extraction process $(A)$ of $3.41 \mathrm{mg} \mathrm{g}^{-1}$ (Table 2) was obtained as using particle size of 60- to 80-mesh compared with that using particle size of 40- to 60-mesh.

Table 2. Fitting Parameters in the Three-site Kinetic Model Under Various Particle Sizes

\begin{tabular}{|c|c|c|c|c|c|c|c|c|c|}
\hline \multirow{2}{*}{$\begin{array}{c}\text { Particle Size } \\
\text { (Mesh) }\end{array}$} & \multicolumn{8}{|c|}{$C_{t}=C_{0} \times\left(1-\exp \left(-k_{0} \times t\right)\right)+C_{1} \times\left(1-\exp \left(-k_{1} \times t\right)\right)+C_{2} \times\left(1-\exp \left(-k_{2} \times t\right)\right)$} \\
\cline { 2 - 10 } & $C_{0}$ & $C_{1}$ & $C_{2}$ & $C_{\infty}$ & $A$ & $k_{0}$ & $k_{1}$ & $k_{2}$ & $\mathrm{r}^{2}$ \\
\cline { 2 - 10 } & \multicolumn{6}{|c|}{$\left(\mathrm{mg} \mathrm{g}^{-1}\right)$} & \multicolumn{7}{c|}{$\left(\mathrm{min}^{-1}\right)$} \\
\hline 20 to 40 & 2.40 & 1.61 & & 4.01 & 1.61 & $>10$ & 0.0177 & & 0.9942 \\
\hline 40 to 60 & 4.12 & 1.32 & 1.74 & 7.18 & 3.06 & $>10$ & 0.0941 & 0.0061 & 0.9983 \\
\hline 60 to 80 & 5.13 & 1.45 & 1.96 & 8.54 & 3.41 & $>10$ & 0.0996 & 0.0069 & 0.9976 \\
\hline
\end{tabular}


So and MacDonald (1986) also observed that oil extraction yield decreases with the increase in particle size. This is probably because the decrease in particle size shortened the mass transfer distance between solids and water (Eikania et al. 2012). Specifically, using particle size of 20- to 40-mesh, the extraction only proceeded in two processes: washing and slower diffusion. This can be attributed to the complex internal structure (Russin et al. 2007).

The extraction kinetic curves were also modeled using the second-order model in the form of Eq. 8 (Fig. 1c). Two stages during the water extraction process were assumed by the second-order model: initially there was intense protein dissolution and releasing in which maximum extraction happens; subsequently, a much slower stage took place that was related to the protein diffusion and the soluble remainder in the solid (Ho et al. 2005). Table 3 presents a summary of the values of relevant parameters. Fitting the experimental data of $C_{\mathrm{t}}$ and $t$ in Table $\mathrm{S} 1$ to Eq. 8, the values of $C_{\mathrm{s}}, k, a$ and $\mathrm{R}^{2}$ were acquired. The values of $C_{0}$ and $A$ were obtained based on Eqs. 10 and 11. As shown in Table 3, the initial extraction yield $\left(C_{0}\right)$, extraction capacity $\left(C_{\mathrm{s}}\right)$, and total protein yield of the water extraction process $(A)$ increased with the decrease in particle size. Similar trends were also observed for $C_{0}, C_{\infty}$ (the theoretical final yield of protein at equilibrium), and $A$ at different particle sizes in the three-site kinetic model (Table 2). Compared with particle sizes of 20- to 40mesh and 40- to 60-mesh, the second-order extraction rate $k$ with a particle size of 60- to 80 -mesh was found to have the minimum value $\left(k=0.008 \mathrm{~g} \mathrm{mg}^{-1} \mathrm{~min}^{-1}\right)$. This might be due to the fact that the protein release was greatly affected by the slower stage, consistent with the results obtained from the three-site model (Vishwanathan et al. 2011).

Table 3. Fitting Parameters in the Second-order Kinetic Model Under Various Particle Sizes

\begin{tabular}{|c|c|c|c|c|c|c|}
\hline \multirow{2}{*}{$\begin{array}{c}\text { Particle Size } \\
\text { (Mesh) }\end{array}$} & \multicolumn{6}{|c|}{$C_{\mathrm{t}} C_{\mathrm{s}}-(1 /(k \times t+a))$} \\
\cline { 2 - 7 } & $\begin{array}{c}a \\
\left(\mathrm{~g} \mathrm{mg}^{-1}\right)\end{array}$ & $\begin{array}{c}C_{0} \\
\left(\mathrm{mg} \mathrm{g}^{-1}\right)\end{array}$ & $\begin{array}{c}C_{\mathrm{s}} \\
\left(\mathrm{mg} \mathrm{g}^{-1}\right)\end{array}$ & $\begin{array}{c}A \\
\left(\mathrm{mg} \mathrm{g}^{-1}\right)\end{array}$ & $\begin{array}{c}k \\
\left(\mathrm{~g} \mathrm{mg}^{-1} \mathrm{~min}^{-1}\right)\end{array}$ & $\mathrm{R}^{2}$ \\
\hline 20 to 40 & 0.49 & 2.29 & 4.31 & 2.02 & 0.011 & 0.9951 \\
\hline 40 to 60 & 0.39 & 4.46 & 7.01 & 2.55 & 0.011 & 0.9738 \\
\hline 60 to 80 & 0.34 & 5.57 & 8.51 & 2.94 & 0.008 & 0.9765 \\
\hline
\end{tabular}
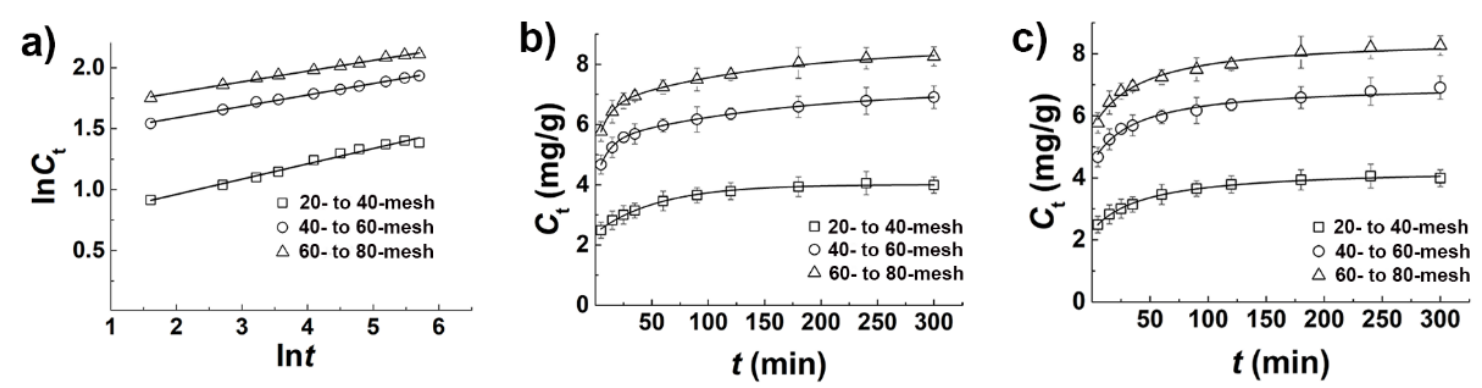

Fig. 1. Kinetic analysis of the water extraction of protein from C. korshinskii Kom. at various particle sizes by three mass transfer models (solid/solvent ratio of 1:20, $\mathrm{NaOH}$ concentration of $0.06 \mathrm{M}$, extraction temperature of $293 \mathrm{~K}$ ): (a) The power-law model; (b) the three-site kinetic extraction model; (c) the second-order model 
From the three-site kinetic model, it could be found that the decrease in particle size of $C$. korshinskii Kom. increased the protein release into the water and led to higher yields in the water extraction process. In previous research, Seikova et al. (2004) studied the extraction process of protein from tomato seed, believing that smaller particle size could lead to higher extraction efficiency. In addition, the experimental data obtained under different particle sizes had the best fit with the three-site extraction model $\left(\mathrm{R}^{2}>0.99\right)$.

\section{Alkaline Concentration}

The water extraction process followed the alkaline extraction process. Therefore, kinetic models were used to study the effect of how the $\mathrm{NaOH}$ concentration used in alkaline extraction may affect the water extraction process. Figure 2 shows the protein extraction kinetic curves with different $\mathrm{NaOH}$ concentration of $C$. korshinskii Kom. The correlated results are presented in Tables 4, 5, and 6. As shown in Table 4, the experimental data obtained under different $\mathrm{NaOH}$ concentrations had a good fit with the power-law model $\left(\mathrm{R}^{2}>0.99\right)$. Increasing $\mathrm{NaOH}$ concentration increased the power-law extraction rate constant $k$. When the $\mathrm{NaOH}$ concentration was $0.1 \mathrm{M}$, the extraction rate constant $k$ reached the maximum of 0.5062 .

Table 4. Fitting Parameters in the Power-law Model Under Various Alkali Concentrations

\begin{tabular}{|c|c|c|c|c|}
\hline \multirow{2}{*}{$\mathrm{NaOH}(\mathrm{M})$} & \multicolumn{4}{|c|}{$\ln C_{\mathrm{t}}=n \ln t+\ln b$} \\
\cline { 2 - 5 } & $b$ & $n$ & $k=b \times n$ & $\mathrm{R}^{2}$ \\
\hline 0.02 & 3.4573 & 0.1006 & 0.3478 & 0.9932 \\
\hline 0.06 & 4.0625 & 0.0937 & 0.3805 & 0.9966 \\
\hline 0.10 & 4.0606 & 0.1247 & 0.5062 & 0.9974 \\
\hline
\end{tabular}

A three-site kinetic model was also used to investigate the effect of $\mathrm{NaOH}$ concentration on the water extraction process. As shown in Table 5, the $C_{1}$ for the faster diffusion process had no obvious change, while the $C_{2}$ for the slower diffusion process increased from 1.66 to $2.84 \mathrm{mg} \mathrm{g}^{-1}$ along with the increase of $\mathrm{NaOH}$ concentration from 0.02 to $0.1 \mathrm{M}$. In addition, the extraction rate constant $k_{2}$ for the slower diffusion process reached the maximum of $0.0087 \mathrm{~min}^{-1}$ when the $\mathrm{NaOH}$ concentration was $0.1 \mathrm{M}$.

Table 5. Fitting Parameters in the Three-site Kinetic Model Under Various Alkali Concentrations

\begin{tabular}{|c|c|c|c|c|c|c|c|c|c|}
\hline \multirow{3}{*}{$\mathrm{NaOH}(\mathrm{M})$} & \multicolumn{8}{|c|}{$C_{\mathrm{t}}=C_{0} \times\left(1-\exp \left(-k_{0} \times t\right)\right)+C_{1} \times\left(1-\exp \left(-k_{1} \times t\right)\right)+C_{2} \times\left(1-\exp \left(-k_{2} \times t\right)\right)$} \\
\cline { 2 - 10 } & $C_{0}$ & $C_{1}$ & $C_{2}$ & $C_{\infty}$ & $A$ & $k_{0}$ & $k_{1}$ & $k_{2}$ & $\mathrm{R}^{2}$ \\
\cline { 2 - 10 } & \multicolumn{7}{|c|}{$\left(\mathrm{mg} \mathrm{g}^{-1}\right)$} & \multicolumn{7}{c|}{$\left(\mathrm{min}^{-1}\right)$} \\
\hline 0.02 & 3.49 & 1.10 & 1.66 & 6.25 & 2.76 & $>10$ & 0.111 & 0.0076 & 0.9904 \\
\hline 0.06 & 4.12 & 1.32 & 1.74 & 7.18 & 3.06 & $>10$ & 0.094 & 0.0061 & 0.9983 \\
\hline 0.10 & 4.51 & 1.07 & 2.84 & 8.42 & 3.91 & $>10$ & 0.090 & 0.0087 & 0.9994 \\
\hline
\end{tabular}

It is likely that the higher alkaline concentration could more effectively destroy the structure of $C$. korshinskii Kom., and lead to the decrease in diffusion resistance of protein 
from cells into water during the slower diffusion process (Zhong et al. 2014). As a result, the total protein yield $(A)$ at equilibrium for the water extraction process with a higher $\mathrm{NaOH}$ concentration was superior to that obtained at lower $\mathrm{NaOH}$ concentration.

For the second-order model, the kinetics of water extraction of protein show a typical pattern for protein yield with time $\left(\mathrm{R}^{2}>0.97\right)$. As shown in Table 6 , an alkaline concentration increased the second-order extraction rate constant $k$ as $\mathrm{NaOH}$ concentration increased from 0.02 to $0.06 \mathrm{M}$, and then decreased $k$ while raising the $\mathrm{NaOH}$ concentration to $0.1 \mathrm{M}$. The maximum $k$ occurred at $0.0108 \mathrm{~g} \mathrm{mg}^{-1} \mathrm{~min}^{-1}$ under $0.06 \mathrm{M} \mathrm{NaOH}$. It is well known that a higher $k$ value suggests a higher extraction rate and more total protein yield at equilibrium. Starting from this perspective, the $0.06 \mathrm{M} \mathrm{NaOH}$ used in alkaline extraction would be more appropriate for the following water extraction of protein from C. korshinskii Kom. However, $C_{\mathrm{s}}, C_{0}$, and $A$ increased with increase of $\mathrm{NaOH}$ concentration from 0.02 to $0.1 \mathrm{M}$. The total protein yield $(A)$ of $4.07 \mathrm{mg} \mathrm{g}^{-1}$ at equilibrium in the water extraction process at $0.1 \mathrm{M} \mathrm{NaOH}$ was almost twofold greater than that obtained at $0.02 \mathrm{M} \mathrm{NaOH}$. Thus, an increase of alkaline concentration used in alkaline extraction might decrease the $k$ value, while increasing protein yield for the water extraction.

Table 6. Fitting Parameters in the Second-order Kinetic Model Under Various Alkali Concentrations

\begin{tabular}{|c|c|c|c|c|c|c|}
\hline \multirow{2}{*}{$\mathrm{NaOH}(\mathrm{M})$} & \multicolumn{6}{|c|}{$C_{\mathrm{t}=C_{\mathrm{s}}-(1 /(k \times t+a))}$} \\
\cline { 2 - 7 } & $\begin{array}{c}a \\
\left(\mathrm{~g} \mathrm{mg}^{-1}\right)\end{array}$ & $\begin{array}{c}C_{0} \\
\left(\mathrm{mg} \mathrm{g}^{-1}\right)\end{array}$ & $\begin{array}{c}C_{\mathrm{s}} \\
\left(\mathrm{mg} \mathrm{g}^{-1}\right)\end{array}$ & $\begin{array}{c}A \\
\left(\mathrm{mg} \mathrm{g}^{-1}\right)\end{array}$ & $\begin{array}{c}k \\
\left(\mathrm{~g} \mathrm{mg}^{-1} \mathrm{~min}^{-1}\right)\end{array}$ & $\mathrm{R}^{2}$ \\
\hline 0.02 & 0.40 & 3.90 & 6.37 & 2.47 & 0.0077 & 0.9733 \\
\hline 0.06 & 0.39 & 4.46 & 7.01 & 2.55 & 0.0108 & 0.9738 \\
\hline 0.10 & 0.24 & 4.85 & 8.92 & 4.07 & 0.0037 & 0.9950 \\
\hline
\end{tabular}

From these three models, it could be found that both $C_{\mathrm{s}}$ and $A$ at equilibrium for the water extraction process increased with an increase of alkaline concentration used in alkaline extraction. Stronger alkaline solutions used in alkaline extraction were more effective to protein release from $C$. korshinskii Kom. in the subsequent water extraction process. However, further increase of alkaline concentration did not significantly enhanced the protein yield. The highest protein yield at $0.1 \mathrm{M} \mathrm{NaOH}$ was $4.07 \mathrm{mg} \mathrm{g}^{-1}$.
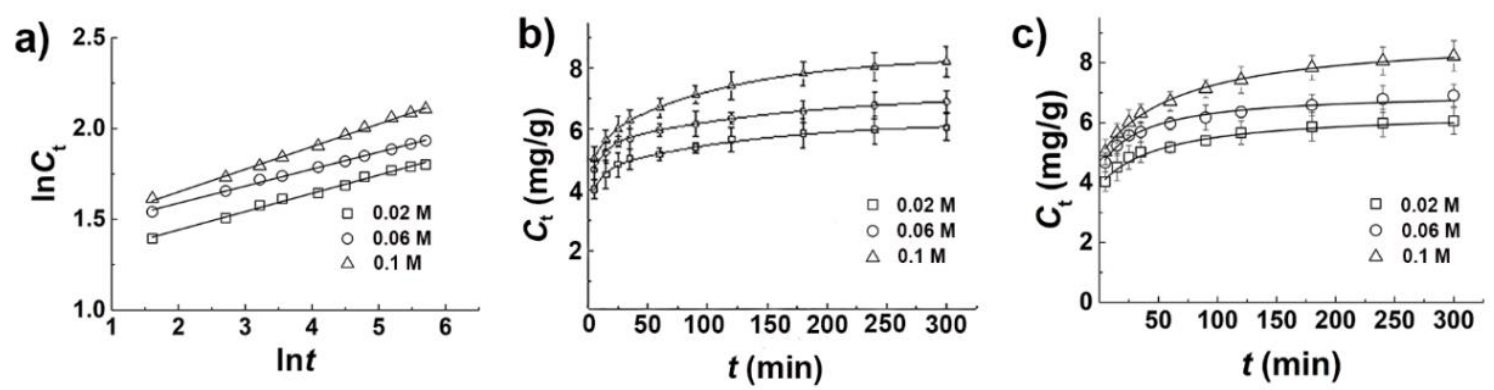

Fig. 2. Kinetic analysis of the water extraction of protein from C. korshinskii Kom. at various alkali concentrations used in alkaline extraction process by three mass transfer models (solid/solvent ratio of 1:20, particle size of 40 - to 60 - mesh, extraction temperature of $293 \mathrm{~K}$ ): (a) The power-law model; (b) the three-site kinetic extraction model; (c) the second-order model 


\section{Extraction Temperature}

In a solid-liquid extraction system, an increase of extraction temperature generally results in decreased dielectric constant of liquid solvent and its surface tension, thus, increasing the internal mass transfer within the solid (Yang et al. 2006; Islam et al. 2014). Therefore, it was expected that higher temperature would promote the water extraction and lead to a higher protein yield. As shown in Fig. 3, the protein extraction yield increased with increasing temperature from 293 to $313 \mathrm{~K}$. Using a power-law model, an increase of extraction temperature increased the extraction rate constant $k$ (Table 7).

Table 7. Fitting Parameters in the Power-law Model Under Various Extraction Temperatures

\begin{tabular}{|c|c|c|c|c|}
\hline \multirow{2}{*}{$\begin{array}{c}\text { Temperature } \\
(\mathrm{K})\end{array}$} & \multicolumn{4}{|c|}{$\ln C_{\mathrm{t}}=n \ln t+\ln b$} \\
\cline { 2 - 5 } & $b$ & $n$ & $k=b \times n$ & $\mathrm{R}^{2}$ \\
\hline 293 & 4.0625 & 0.0937 & 0.3805 & 0.9966 \\
\hline 303 & 4.1262 & 0.1123 & 0.4635 & 0.9735 \\
\hline 313 & 4.4921 & 0.1358 & 0.6100 & 0.9670 \\
\hline
\end{tabular}

For a three-site kinetic model, Table 8 shows that an increase of temperature had no significant effect on the protein yield for the washing process, while an increase was seen for both the faster and slower diffusion processes. The $A$ at $313 \mathrm{~K}$ was $6.19 \mathrm{mg} \mathrm{g}^{-1}$, almost twofold greater than that at $293 \mathrm{~K}$. The maximum $C_{1}$ and $C_{2}$ obtained at $313 \mathrm{~K}$ were 3.23 and $2.96 \mathrm{mg} \mathrm{g}^{-1}$, respectively. Interestingly, $C_{1}$ gradually surpassed $C_{2}$ as the extraction temperature was raised from 293 to $313 \mathrm{~K}$. The results indicated that the faster diffusion process dominated the water extraction of protein at a higher temperature. The raising of extraction temperature was an effective method to enhance the protein extraction efficiency of the water extraction process.

Table 8. Fitting Parameters in the Three-site Kinetic Model Under Various Extraction Temperatures

\begin{tabular}{|c|c|c|c|c|c|c|c|c|c|}
\hline \multirow{2}{*}{$\begin{array}{c}\text { Temperature } \\
(\mathrm{K})\end{array}$} & \multicolumn{8}{|c|}{$C_{\mathrm{t}}=C_{0} \times\left(1-\exp \left(-k_{0} \times t\right)\right)+C_{1} \times\left(1-\exp \left(-k_{1} \times t\right)\right)+C_{2} \times\left(1-\exp \left(-k_{2} \times t\right)\right)$} \\
\cline { 2 - 10 } & $C_{0}$ & $C_{1}$ & $C_{2}$ & $C_{\infty}$ & $A$ & $k_{0}$ & $k_{1}$ & $k_{2}$ & $\mathrm{R}^{2}$ \\
\cline { 2 - 10 } & \multicolumn{7}{|c|}{$\left(\mathrm{mg} \mathrm{g}^{-1}\right)$} & \multicolumn{7}{c|}{$\left(\mathrm{min}^{-1}\right)$} \\
\hline 293 & 4.12 & 1.32 & 1.74 & 7.18 & 3.06 & $>10$ & 0.0941 & 0.0061 & 0.9983 \\
\hline 303 & 3.92 & 1.91 & 1.86 & 7.69 & 3.77 & $>10$ & 0.0952 & 0.0098 & 0.9960 \\
\hline 313 & 3.92 & 3.23 & 2.96 & 10.11 & 6.19 & $>10$ & 0.0978 & 0.0054 & 0.9996 \\
\hline
\end{tabular}

For a second-order kinetic model, Table 9 shows that $C_{\mathrm{s}}$ and $A$ increased along with temperature increase. The maximum value of $A$ was $5.08 \mathrm{mg} \mathrm{g}^{-1}$ at $313 \mathrm{~K}$, which was nearly twice that at $293 \mathrm{~K}$. However, extraction temperature decreased the second-order extraction rate constant $k$ as the temperature increased from 303 to $313 \mathrm{~K}$. The $k$ reached its maximum value of $0.0115 \mathrm{~g} \mathrm{mg}^{-1} \mathrm{~min}^{-1}$ at $303 \mathrm{~K}$ (Table 9). 
Table 9. Fitting Parameters in the Second-order Kinetic Model Under Various Extraction Temperatures

\begin{tabular}{|c|c|c|c|c|c|c|}
\hline \multirow{2}{*}{$\begin{array}{c}\text { Temperature } \\
(\mathrm{K})\end{array}$} & \multicolumn{6}{|c|}{$C_{\mathrm{t}}=C_{\mathrm{s}^{-}}(1 /(k \times t+a))$} \\
\cline { 2 - 7 } & $\begin{array}{c}a \\
\left(\mathrm{~g} \mathrm{mg}^{-1}\right)\end{array}$ & $\begin{array}{c}C_{0} \\
\left(\mathrm{mg} \mathrm{g}^{-1}\right)\end{array}$ & $\begin{array}{c}C_{\mathrm{s}} \\
\left(\mathrm{mg} \mathrm{g}^{-1}\right)\end{array}$ & $\begin{array}{c}A \\
\left(\mathrm{mg} \mathrm{g}^{-1}\right)\end{array}$ & $\begin{array}{c}k \\
\left(\mathrm{~g} \mathrm{mg}^{-1} \mathrm{~min}^{-1}\right)\end{array}$ & $\mathrm{R}^{2}$ \\
\hline 293 & 0.39 & 4.46 & 7.01 & 2.55 & 0.0108 & 0.9738 \\
\hline 303 & 0.28 & 4.16 & 7.78 & 3.62 & 0.0115 & 0.9911 \\
\hline 313 & 0.20 & 4.47 & 9.55 & 5.08 & 0.0087 & 0.9734 \\
\hline
\end{tabular}

The Arrhenius equation (Eq. 14) was employed to understand the relationship between extraction temperatures $T$ and the second-order extraction rate constant $k$ (Milic et al. 2014),

$$
k=k_{0} \times \exp (-E /(R \times T))
$$

where $k_{0}$ represents the temperature independent factor $\left(\mathrm{g} \mathrm{mg}^{-1} \mathrm{~min}^{-1}\right), E$ refers to the activation energy $(\mathrm{J} / \mathrm{mol})$, and $R$ represents the universal gas constant $\left(8.31 \mathrm{~J} \mathrm{~mol}^{-1} \mathrm{~K}^{-1}\right)$. According to Eq. 14, the $k$ value increases with increasing extraction temperature. However, the $k$ value in the current research decreased when the extraction temperature increased from 303 to $313 \mathrm{~K}$, which was not consistent with the Eq. 14. It is likely that the protein conformation and degree of protein unfolding were altered by the further increase of extraction temperature, which affected the mass transfer behavior of protein in the water extraction process (Zhong et al. 2014).

From these three models, it was concluded that an appropriate increase in extraction temperature was more effective for protein release from C. korshinskii Kom. in the water extraction process. However, high temperature might lead to protein denaturation.
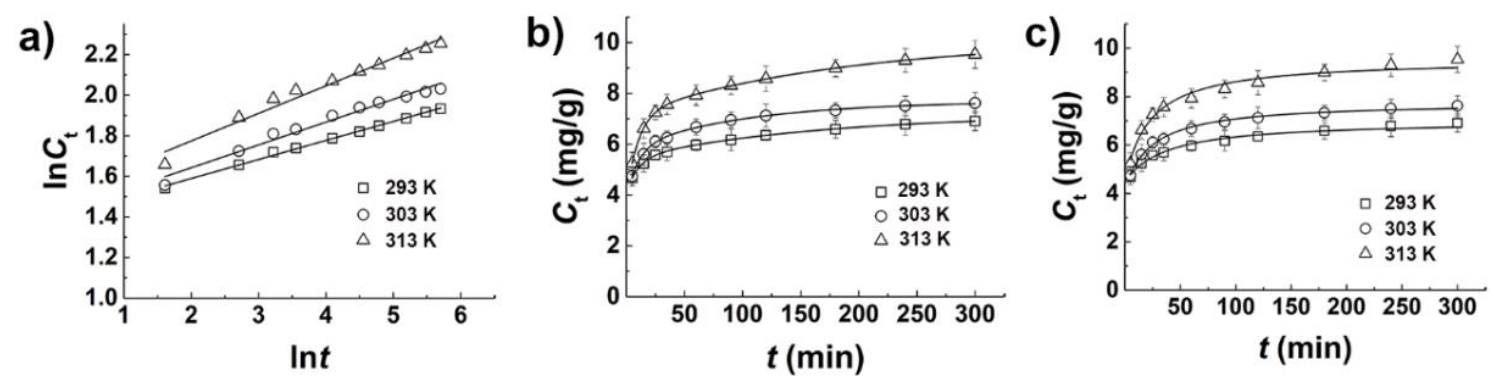

Fig. 3. Kinetic analysis of the water extraction of protein from C. korshinskii Kom. at various extraction temperatures by three mass transfer models (solid/solvent ratio of $1: 20, \mathrm{NaOH}$ concentration of $0.06 \mathrm{M}$, particle size of 40 - to 60 -mesh): (a) The power-law model; (b) the threesite kinetic extraction model; (c) the second-order model

\section{Mass Conservation of Protein}

The protein in C. korshinskii Kom. was extracted by a two-step extraction procedure. The mass equilibrium details accounting of protein extracted from $C$. korshinskii Kom. at various operation parameters are presented in Table 10. The maximum protein yield of the two-step extraction procedure was obtained when using a particle size of 60 - to 80 -mesh at $0.06 \mathrm{M} \mathrm{NaOH}$ and $293 \mathrm{~K}$. The total protein yield was $42.3 \mathrm{mg} \mathrm{g}^{-1}$ with a theoretical yield of $52.9 \%$. For the water extraction process, a high protein yield of 9.54 
$\mathrm{mg} \mathrm{g}^{-1}(11.9 \%$ of theoretical yield) was achieved using a particle size of 40 - to 60 -mesh at $0.06 \mathrm{M} \mathrm{NaOH}$ and $313 \mathrm{~K}$. A high protein yield for the alkaline extraction process was obtained with a particle size of 60 - to 80 -mesh at $0.06 \mathrm{M} \mathrm{NaOH}$. The protein yields for both alkaline and water extraction processes increased along with an increase in alkaline concentration and extraction temperature and decreased with increasing particle size.

Table 10. Mass Equilibrium Accounting of Protein Extracted From C. korshinskii Kom. at Various Operation Parameters by Two-step Extraction Process

\begin{tabular}{|c|c|c|c|c|c|c|}
\hline $\begin{array}{c}\text { Protein Content } \\
(\mathrm{mg} / \mathrm{g})\end{array}$ & $\begin{array}{c}\text { 40- to 60- } \\
\text { mesh }^{\dagger}\end{array}$ & $\begin{array}{c}\text { 60- to 80- } \\
\text { mesh }^{\dagger}\end{array}$ & $\begin{array}{l}0.02 \mathrm{M} \\
\mathrm{NaOH}^{\ddagger}\end{array}$ & $\begin{array}{c}0.1 \mathrm{M} \\
\mathrm{NaOH}^{\ddagger}\end{array}$ & $\begin{array}{c}303 \\
\mathrm{~K}^{\S}\end{array}$ & $\begin{array}{c}313 \\
\mathrm{~K}^{\S}\end{array}$ \\
\hline $\begin{array}{c}\text { Total protein of } \\
\text { C. korshinskii Kom. }\end{array}$ & 80.00 & 80.00 & 80.00 & 80.00 & 80.00 & 80.00 \\
\hline $\begin{array}{l}\text { Protein yield of } \\
\text { alkaline extraction }\end{array}$ & 24.48 & 34.02 & 22.70 & 29.29 & 25.89 & 25.92 \\
\hline $\begin{array}{c}\text { Protein yield of } \\
\text { water extraction }\end{array}$ & 6.91 & 8.26 & 6.06 & 8.22 & 7.62 & 9.54 \\
\hline $\begin{array}{l}\text { Residual protein of } \\
\text { samples }\end{array}$ & 48.62 & 37.71 & 51.25 & 42.49 & 46.48 & 44.54 \\
\hline \multicolumn{7}{|c|}{$\begin{array}{l}\dagger \text { Extraction temperature of } 293 \mathrm{~K} \text {, alkali concentration of } 0.06 \mathrm{M} \text { for the alkaline extraction } \\
\text { process; } \\
\text { ¥ Particle size of } 40 \text { - to } 60 \text {-mesh, extraction temperature of } 293 \mathrm{~K} \text {; } \\
\text { § Particle size of } 40 \text { - to } 60 \text {-mesh, alkali concentration of } 0.06 \mathrm{M} \text { for the alkaline extraction } \\
\text { process; } \\
\text { The solid/solvent ratio was } 1: 20 \text { under different operation parameters. The extraction time was } \\
30 \text { min for the alkaline extraction process, and } 300 \text { min for the water extraction process. }\end{array}$} \\
\hline
\end{tabular}

\section{CONCLUSIONS}

1. The water extraction process of protein was studied systematically in terms of a power-law model, a three-site kinetic extraction model, and a second-order model. The experimental data obtained under different extraction conditions had the best fit with the three-site extraction model $\left(R^{2}>0.99\right)$, which indicated that the water extraction process, which included washing and faster and slower stages, had the slower stage as the rate-limiting step.

2. For the water extraction process, decreasing particle size, increasing $\mathrm{NaOH}$ concentration, or raising extraction temperature could enhance the protein yield. The extraction temperature was the key factor affecting protein extraction yield.

3. For the water extraction process, a high protein yield of $9.54 \mathrm{mg} \mathrm{g}^{-1}(11.9 \%$ of theoretical yield) was achieved using a particle size of 40 - to 60 -mesh at $0.06 \mathrm{M} \mathrm{NaOH}$ and $313 \mathrm{~K}$.

\section{ACKNOWLEDGMENTS}

This research was funded by the Special Fund for Agro-scientific Research in the Public Interest, Grant No. 201503135-15, the National Natural Science Foundation of 
China, Grant No. 31470610, 21576212, and the Natural Science Foundation of Tianjin, Grant No. 19PTSYJC00060.

\section{REFERENCES CITED}

Cheng, X., Huang, M., Si, B. C., Yu, M., and Shao, M. (2013). "The differences of water balance components of Caragana korshinkii grown in homogeneous and layered soils in the desert-loess plateau transition zone," J. Arid. Environ. 98, 10-19. DOI: 10.1016/j.jaridenv.2013.07.007

Cheung, Y. C., and Wu, J. Y. (2013). "Kinetic models and process parameters for ultrasound-assisted extraction of water-soluble components and polysaccharides from a medicinal fungus," Biochem. Eng. J. 79, 214-220. DOI: 10.1016/j.bej.2013.08.009

Eikania, M. H., Golmohammad, F., and Homami, S. S. (2012). "Extraction of pomegranate (Punica granatum L.) seed oil using superheated hexane," Food Bioprod. Process. 90(1), 32-36. DOI: 10.1016/j.fbp.2011.01.002

El-Adawy, T. A., Rahma, E. H., El-Bedawey, A. A, and Gafar, A. F. (2001). "Nutritional potential and functional properties of sweet and bitter lupin seed protein isolates," Food Chem. 74(4), 455-462. DOI: 10.1016/S0308-8146(01)00163-7

Goula, A. M. (2013). "Ultrasound-assisted extraction of pomegranate seed oil - Kinetic modeling," J. Food Eng. 117(4), 492-498. DOI: 10.1016/j.jfoodeng.2012.10.009

Ho, Y. S., Harouna-Oumarou, H. A., Fauduet, H., and Porte, C. (2005). "Kinetics and model building of leaching of water-soluble compounds of Tilia sapwood," Sep. Purif. Technol. 45(3), 169-173. DOI: 10.1016/j.seppur.2005.03.007

Hou, F., Ding, W., Qu, W., Oladejo, A. O., Xiong, F., Zhang, W., He, R., and Ma, H. (2017). "Alkali solution extraction of rice residue protein isolates: Influence of alkali concentration on protein functional, structural properties and lysinoalanine formation," Food Chem. 218, 207-215. DOI: 10.1016/j.foodchem.2016.09.064

Islam, M. N., Jo, Y. T., and Park, J. H. (2014). "Remediation of soil contaminated with lubricating oil by extraction using subcritical water," J. Ind. Eng. Chm. 20(4), 15111516. DOI: 10.1016/j.jiec.2013.07.040

Kiew, P. L., and Mat Don, M. (2013). "Screening and empirical kinetic models of collagen extraction from selected Malaysian freshwater fish," J. Food Process Eng. 36(4), 428-438. DOI: 10.1111/j.1745-4530-2012-00683-X

Li, Q., Liu, G. B., Xu, M., and Zhang, Z. (2014). "Relationship of soil erodibility, soil physical properties, and root biomass with the age of Caragana Korshinskii Kom. plantations on the Hilly Loess Plateau, China," Arid Land Res. Manag. 28(3), 311324. DOI: $10.1080 / 15324982.2013 .855957$

Lowry, O. H., Rosebrough, N. J., Farr, A. L., and Randall, R. J. (1951). "Protein measurement with the Folin phenol reagent," J. Biol. Chem. 193(1), 265-275. DOI: 10.1515/bchm2.1951.286.1-6.270

Milic, P. S., Rajkovic, K. M., Bekric, D. M., Stamenkovic, O. S., and Veljkovic, V. B. (2014). "The kinetic and thermodynamic analysis of ultrasound-extraction of minerals from aerial parts of white lady's bedstraw (Galium mollugo L.)," Chem. Eng. Res. Des. 92(7), 1399-1409. DOI: 10.1016/j.cherd.2013.10.024 
Ndlela, S. C., De Moura, J. M. L. N., Olson, N. K., and Johnson, L. A. (2012). "Aqueous extraction of oil and protein from soybeans with subcritical water," J. Am. Oil Chem. Soc. 89(6), 1145-1153. DOI: 10.1007/s11746-011-1993-7

Qu, W., Pan, Z., and Ma, H. (2010). "Extraction modeling and activities of antioxidants from pomegranate marc," J. Food Eng. 99(1), 16-23. DOI:

10.1016/j.jfoodeng.2010.01.020

Rakotondramasy-Rabesiaka, L., Havet, J. L., Porte, C., and Fauduet, H. (2007). "Solidliquid extraction of protopine from Fumaria officinalis L. - Analysis determination, kinetic reaction and model building," Sep. Purif. Technol. 54(2), 253-261. DOI: 10.1016/j.seppur.2006.09.015

Russin, T. A., Arcand, Y., and Boye, J. I. (2007). "Particle size effect on soy protein isolate extraction," J. Food Process. Pres. 31(3), 308-319. DOI: 10.1111/j.17454549.2007.00127.x

Seikova, I., Simeonov, E., and Ivanova, E. (2004). "Protein leaching from tomato seed experimental kinetics and prediction of effective diffusivity," J. Food Eng. 61(2), 165-171. DOI: 10.1016/s0260-8774(03)00083-9

Sivapriya, M., and Leela, S. (2007). "Isolation and purification of a novel antioxidant protein from the water extract of Sundakai (Solanum torvum) seeds," Food Chem. 104(2), 510-517. DOI: 10.1016/j.foodchem.2006.11.060

So, G. C., and MacDonald, D. G. (1986). "Kinetics of oil extraction from canola (rapeseed)," Can. J. Chem. Eng. 64(1), 80-86. DOI: 10.1002/cjce.5450640112

Vishwanathan, K. H., Singh, V., and Subramanian, R. (2011). "Influence of particle size on protein extractability from soybean and okara," J. Food Eng. 102(3), 240-246. DOI: $10.1016 /$ j.jfoodeng.2010.08.026

Yang, Q., Yin, J., Li, G., Qi, L., Yang, F., Wang, R., and Li, G. (2014). "Reference gene selection for qRT-PCR in Caragana korshinskii Kom. under different stress conditions," Mol. Biol. Rep. 41(4), 2325-2334. DOI: 10.1007/s11033-014-3086-9

Yang, Y., and Hildebr, F. (2006). "Phenanthrene degradation in subcritical water," Anal. Chim. Acta. 555(2), 364-369. DOI: 10.1016/j.aca.2005.08.078

Zhang, C., Sanders, J. P., and Bruins, M. E. (2014). "Critical parameters in cost-effective alkaline extraction for high protein yield from leaves," Biomass Bioenerg. 67, 466472. DOI: 10.1016/j.biombioe.2014.05.020

Zhang, Z., Wang, Y., Dai, C., He, R., and Ma, H. (2018). "Alkali extraction of rice residue protein isolates: Effects of alkali treatment conditions on lysinoalanine formation and structural characterization of lysinoalanine-containing protein," Food Chem. 261, 176-183. DOI: 10.1016/j.foodchem.2018.04.027

Zhong, C., Sun, Z., Zhou, Z., Jin, M. J., Tan, Z. L., and Jia, S. R. (2014a). "Chemical characterization and nutritional analysis of protein isolates from Caragana korshinskii Kom.," J. Agr. Food. Chem. 62(14), 3217-3222. DOI: 10.1021/jf500349s

Zhong, C., Zhou, Z., Zhang, Y. M., Jia, S. R., Sun, Z., and Dale, B. E. (2014b). "Integrating kinetics with thermodynamics to study the alkaline extraction of protein from Caragana korshinskii Kom," Biotechnol. Bioeng. 111(9), 1801-1808. DOI: 10.1002/bit.25229 
Zhong, C., Wang, R., Zhou, Z., Jia, S. R., Tan, Z. L., and Han, P. P. (2012). "Functional properties of protein isolates from Caragana korshinskii Kom. extracted by three different methods," J. Agr. Food. Chem. 60(41), 10337-10342. DOI:

$10.1021 / \mathrm{jf} 303442 \mathrm{u}$

Article submitted: February 6, 2020; Peer review completed: April 18, 2020; Revised version received and accepted: May 6, 2020; Published: May 14, 2020.

DOI: 10.15376/biores.15.3.5032-5048 


\section{APPENDIX}

\section{Supplementary Materials}

Table S1. Protein Extraction Yield from C. Korshinskii Kom. at a Given Extraction Time $t$ for Various Particle Sizes

\begin{tabular}{|c|c|c|c|}
\hline \multirow{2}{*}{$t(\min )$} & \multicolumn{3}{|c|}{$C_{\mathrm{t}}\left(\mathrm{mg} \mathrm{g}^{-1}\right)$} \\
\cline { 2 - 4 } & 20 - to 40-mesh & $40-$ to 60 -mesh & 60 - to 80-mesh \\
\hline 5 & $2.49 \pm 0.26$ & $4.67 \pm 0.31$ & $5.77 \pm 0.33$ \\
\hline 15 & $2.82 \pm 0.31$ & $5.24 \pm 0.34$ & $6.43 \pm 0.37$ \\
\hline 25 & $3.00 \pm 0.31$ & $5.58 \pm 0.17$ & $6.79 \pm 0.26$ \\
\hline 35 & $3.14 \pm 0.24$ & $5.69 \pm 0.34$ & $6.95 \pm 0.17$ \\
\hline 60 & $3.46 \pm 0.32$ & $5.97 \pm 0.22$ & $7.24 \pm 0.24$ \\
\hline 90 & $3.65 \pm 0.25$ & $6.17 \pm 0.42$ & $7.49 \pm 0.38$ \\
\hline 120 & $3.79 \pm 0.28$ & $6.35 \pm 0.19$ & $7.66 \pm 0.18$ \\
\hline 180 & $3.94 \pm 0.33$ & $6.59 \pm 0.35$ & $8.05 \pm 0.51$ \\
\hline 240 & $4.06 \pm 0.38$ & $6.79 \pm 0.45$ & $8.20 \pm 0.36$ \\
\hline 300 & $3.99 \pm 0.27$ & $6.91 \pm 0.37$ & $8.26 \pm 0.31$ \\
\hline
\end{tabular}

Table S2. Protein Extraction Yield from C. Korshinskii Kom. at a Given Extraction Time $t$ for Various Alkali Concentrations

\begin{tabular}{|c|c|c|c|}
\hline \multirow{2}{*}{$t(\min )$} & \multicolumn{3}{|c|}{$C_{\mathrm{t}}\left(\mathrm{mg} \mathrm{g}^{-1}\right)$} \\
\cline { 2 - 4 } & $0.02 \mathrm{M}$ & $0.06 \mathrm{M}$ & $0.1 \mathrm{M}$ \\
\hline 5 & $4.03 \pm 0.33$ & $4.67 \pm 0.31$ & $5.02 \pm 0.42$ \\
\hline 15 & $4.51 \pm 0.45$ & $5.24 \pm 0.34$ & $5.65 \pm 0.33$ \\
\hline 25 & $4.84 \pm 0.4$ & $5.58 \pm 0.17$ & $6.01 \pm 0.43$ \\
\hline 35 & $5.02 \pm 0.34$ & $5.69 \pm 0.22$ & $6.31 \pm 0.31$ \\
\hline 60 & $5.18 \pm 0.2$ & $5.97 \pm 0.22$ & $6.71 \pm 0.32$ \\
\hline 90 & $5.40 \pm 0.17$ & $6.17 \pm 0.42$ & $7.13 \pm 0.3$ \\
\hline 120 & $5.67 \pm 0.39$ & $6.35 \pm 0.19$ & $7.43 \pm 0.45$ \\
\hline 180 & $5.87 \pm 0.47$ & $6.59 \pm 0.35$ & $7.84 \pm 0.4$ \\
\hline 240 & $5.99 \pm 0.46$ & $6.79 \pm 0.45$ & $8.05 \pm 0.47$ \\
\hline 300 & $6.06 \pm 0.44$ & $6.91 \pm 0.37$ & $8.22 \pm 0.51$ \\
\hline
\end{tabular}


Table S3. Protein Extraction Yield from C. Korshinskii Kom. at a Given Extraction Time $t$ under Various Extraction Temperatures

\begin{tabular}{|c|c|c|c|}
\hline \multirow{2}{*}{$t(\min )$} & \multicolumn{3}{|c|}{$C_{t}\left(\mathrm{mg} \mathrm{g}^{-1}\right)$} \\
\cline { 2 - 4 } & $293 \mathrm{~K}$ & $303 \mathrm{~K}$ & $313 \mathrm{~K}$ \\
\hline 5 & $4.67 \pm 0.31$ & $4.74 \pm 0.32$ & $5.25 \pm 0.44$ \\
\hline 15 & $5.24 \pm 0.34$ & $5.61 \pm 0.43$ & $6.62 \pm 0.39$ \\
\hline 25 & $5.58 \pm 0.17$ & $6.11 \pm 0.25$ & $7.25 \pm 0.28$ \\
\hline 35 & $5.69 \pm 0.34$ & $6.25 \pm 0.28$ & $7.57 \pm 0.40$ \\
\hline 60 & $5.97 \pm 0.22$ & $6.68 \pm 0.32$ & $7.93 \pm 0.40$ \\
\hline 90 & $6.17 \pm 0.42$ & $6.95 \pm 0.32$ & $8.31 \pm 0.36$ \\
\hline 120 & $6.35 \pm 0.19$ & $7.12 \pm 0.44$ & $8.58 \pm 0.50$ \\
\hline 180 & $6.59 \pm 0.35$ & $7.33 \pm 0.30$ & $8.99 \pm 0.34$ \\
\hline 240 & $6.79 \pm 0.45$ & $7.51 \pm 0.39$ & $9.30 \pm 0.47$ \\
\hline 300 & $6.91 \pm 0.37$ & $7.62 \pm 0.42$ & $9.54 \pm 0.55$ \\
\hline
\end{tabular}

